\section{The effects of Tui Na massage on the growth status of children under five years of age with KMS T status (low weight gain)}

\author{
Annif Munjidah, Fitria Dwi Anggraini \\ Universitas Nahdlatul Ulama Surabaya, \\ Indonesia
}

\begin{abstract}
Nutritional problem in urban area is generally caused by food absorption disorder which can be treated by Tui Na massage. This article was aimed to investigate the effect of Tui Na massage on the growth status of children less than five years of age with KMS T status (low weight gain in Indonesia medical record). This quasiexperimental study was conducted by implementing pre-and-posttest design with control group. This study involved 26 children less than five years of age with KMS $\mathrm{T}$ as research samples chosen by simple random sampling technique. The results of analysis using paired t-test on the effect before and after Tui $\mathrm{Na}$ massage showed $\mathrm{p}=0.019<\alpha=0.05$, while independent t-test in control and treatment group obtained $p=0.065>\alpha=0.05$. It shows that Tui Na massage affects the growth status of children under five years of age. Based on those results, midwives are expected to be able to perform Tui Na massage as an effort to develop the growth status of children under five years of age.
\end{abstract}

\section{Introduction}

All parents expect their children to grow normally. Growth is associated with the changes in quantity and size, or dimension of cells, organs, and individuals which can be measured by weight and height. ${ }^{1}$ Positive growth will bring advantage for the children's future as the nation's next generation. On the contrary, health problem will serve as an obstacle for the continuation of the next generation. ${ }^{2}$ Growth problem in Indonesia is highly associated with low nutrition and obesity. In Indonesia, millions of children under the age of five are suffered from nutritional problem. ${ }^{3}$

UNICEF noted that millions of children in Southeast Asia and South Asia are having nutritional problems. One out of three children less than five years of age are suffered growth problems (low height-forage/stunted growth) and nearly one-fifth are suffered from low weight below average/underweight. ${ }^{4}$ According to the results of the 2013 Basic Health Research Data, $18.8 \%$ of children fewer than five years of age experience low nutrition and $29 \%$ experience stunting. This prevalence rate is above the universally consented threshold published by World Health Organization (WHO), which is $20 \%$ or onefifth of the total number of children less than five years of age in a country.

Low nutrition is a condition in which the body weight is below WHO growth curve; whereas stunting is a condition in which a child is failed to grow due to low nutrition and recurrent diseases for a long time during the fetal age until the first two years of a child's life. ${ }^{3}$ Some related factors to nutritional problems are low family income (economic factor), knowledge about food nutrition, birth spacing, prejudices against certain foods, adverse food abstinence traditions, and excessive preference for certain foods. Nutritional problems in urban areas are mostly not caused by economic factors but resulted from food absorption disorders.

Low nutrition and weight in toddlerhood will result a less optimal physical and mental health development in adulthood. Whilst, children with stunting are at risk of having an IQ of 5-10 points lower than normal children. ${ }^{5}$

An approach is needed to handle children growth problems by overcoming eating difficulties, safely increase the capacity to absorb nutrients and minimize the adverse effects on children. Recently, a baby massage technique, Tui Na massage, has been developed. This massage is performed by sliding technique (Effleurage or Tui), massaging technique (Petrissage or $\mathrm{Nie}$ ), tapping technique (tapotement or Da), rubbing, pulling, twisting, shaking, and vibrating certain points in the body to alter the body's energy flow. Tui Na Massage is a specific massage technique for eating difficulties in children under five years of age by facilitating blood circulation to the spleen and digestive organs.

The results of the research by Zhen Huan Liu and Li Ting Cen in Guangzhou in 2009 showed that Tui Na massage has a positive effect on the development of nerves and blood circulation in infants. ${ }^{6}$ Similar research by Joko Widodo showed that Tui $\mathrm{Na}$ massage can facilitate the blood flow to the digestion and spleen to increase the absorption of nutrients. ${ }^{7}$

Wonokromo is one of the villages in Surabaya with heterogeneous communities and good health activities and health services since 2015. We chose RW (Rukun Warga or community Association) 02 in this area as
Correspondence: Annif Munjidah, Universitas Nahdlatul Ulama Surabaya, SMEA Street 57 , Surabaya, Jawa Timur 60243, Indonesia,

Tel.: +62.31.8291920 - Fax: +62.31.8298582

E-mail: annifmunjidah@unusa.ac.id.

Key words: Tui $\mathrm{Na}$ massage, growth status, child.

Acknowledgments: the authors would like to thanks to Rector of Universitas Nahdlatul Ulama.

Contributions: the authors contributed equally.

Conflict of interests: the authors declare no potential conflict of interest.

Funding: none.

Conference presentation: part of this paper was presented at the $3^{\text {rd }}$ International Symposium of Public Health, 2018 October 31 - November 1, Universitas Airlangga, Surabaya, Indonesia

Dedication: the article is dedicated to Universitas Nahdlatul Ulama.

Received for publication: 28 July 2019.

Revision received: 9 September 2019.

Accepted for publication: 15 October 2019.

This work is licensed under a Creative Commons Attribution NonCommercial 4.0 License (CC BY-NC 4.0).

(C) Copyright: the Author(s), 2019

Licensee PAGEPress, Italy

Journal of Public Health in Africa 2019; 10(s1):1205 doi:10.4081/jphia.2019.1205

research target. In 2016, we obtained data from Posyandu (integrated health post) about the children under five years of age living in RW 02 Wonokromo. The initial research showed that most mothers with 2 or more children under five years of age in one household register do not use contraception. It resulted close birth spacing. In 2017, the researchers worked with the Nutrition Center of Puskesmas (community health center) Wonokromo concerning the nutrition problem among the children under five years of age in Wonokromo. The observation showed that there were 38 toddlers with poor nutritional status, one of them is suffered from congenital defects, two toddlers moved to other houses, and 35 toddlers lived permanently in Wonokromo village. At that time, the researchers provided assistance in the form of counseling and demonstrations related to low nutrition given during community service activities. Following the activities of Nutrition Center in the Posyandu, some toddlers did not want to eat 
the supplemental food, while some others were looking out of it. We were then encouraged to study the effect of Tui $\mathrm{Na}$ massage on weight gain in children under five years of age. Therefore, this article provides our analysis on the effect of Tui $\mathrm{Na}$ massage to growth status of children less than five years of age with KMS T status.

\section{Materials and Methods}

This pre-experimental study was conducted by implementing quasiexperimental research design with pre-and-posttest design of a control group. Observations will be made after treatment to two groups: treatment group and control group. Tui Na massage intervention was given to the treatment group, whereas the control group received Effleurage massage or light stroking massage. Before the intervention of Tui $\mathrm{Na}$ and Effleurage massage, the children's body weight was measured as pre-test data. After the intervention of Tui $\mathrm{Na}$ and Effleurage massage, the body weight was measured as post-test data. This study involved 26 children under five years of age with KMS $\mathrm{T}$ status chosen by simple random sampling technique. The study was taken place in Wonokromo Surabaya from February to July 2018. The instrument used as the variable of the implementation of Tui $\mathrm{Na}$ massage is standard operating procedure (SOP). Weight scale is used to measure the dependent variable of growth status. The data were collected directly as primary data and analyzed by using paired t-test and independent t-test.

\section{Results}

The data were obtained from 26 respondents, respectively 13 respondents from the control group and 13 respondents from the treatment group. The respondents' characteristics including age and sex were presented in Table 1 as follows, based on the pre-treatment assessment on the two groups.

Table 1 shows that almost all children were in the age of three to five years old. At this age, they have been enrolled in preschool and doing many activities. They should have felt hungry and not hesitate to ask for food from their parents. Eating difficulties were often experienced by children in the age of one to three years. ${ }^{8}$ Almost half of the respondents received exclusive breastfeeding. The role of exclusive breastfeeding is very important to digestion functions and absorption of nutrients in infants up to the age of 6 months. It is in line with previous study in the IDAI ASI (a book about breastfeeding) where digestive tract maturation is stimulated by breast milk facilitated by the colostrum. ${ }^{9}$

According to Table 2, the average body weight of the respondents before the intervention is $9.3 \mathrm{~kg}$ and $10.4 \mathrm{~kg}$ for control and treatment group, respectively.

According to Table 3, after receiving Tui Na massage, almost all (76.9\%) children had gained weight. Whilst, almost half (38.5\%) in the control group gained weight.

The result of the analysis on the effect of Tui $\mathrm{Na}$ massage by paired t-test on the treatment group showed $p$ value of 0.019 . It showed the value of $\operatorname{sig}<\alpha(0.05)$, which meant that there was a significant effect before and after receiving Tui Na massage to KMS T growth status among children under five years of age. Whilst, the result of analysis obtained in the control and treatment group by independent sample t-test showed the result of $p=0.065$. This result indicated the value of $\mathrm{sig}>\alpha(0.05)$ which means that $\mathrm{H} 0$ is accepted. It shows that there was no significant effect of Tui $\mathrm{Na}$ massage on KMS T growth status among children under five years of age in the treatment group, and there was no effect of effleurage massage on KMS T growth status among children under five years of age in the control group (Table 4).

\section{Discussion}

The results of the analysis informed that KMS T growth status was influenced by Tui $\mathrm{Na}$ massage. Most mothers in the treatment group stated that following the intervention, their children sleep well, often feel hungry, and show higher appetite compared to before the intervention. It is in line with the theory on the activity of vagus nerve which affects the food absorption mechanism. The massage received by the children less than five years of age will increase a vagal tone. The research showed that children who received the massage experienced an increase in the vagal tone, so that the branches of the vagus nerve (the 10th brain nerve) will increase the level of absorbing enzymes: gastrin and insulin. Thus, food absorption activity will get better. ${ }^{10}$

Tui Na massage is also one of the nonpharmacological treatments that can increase appetite, reduce eating unwillingness, nausea, and vomit. One of its advantages compared to other types of massages is the ability to focus on specific problems and not only work on the muscles, bones and joints, but also the body's energy at a deeper level to keep it in balance. Besides, this massage has fewer side effects compared to chemicalbased drugs. It is consistent with previous study that Tui Na massage is a more specific massage technique by facilitating blood circulation in spleen and digestion, through modification of needle-free acupuncture. ${ }^{11}$ This technique works by placing pressure on the body's meridian points or energy flow lines so it is relatively easier to perform compared to acupuncture. Tui Na consists of 8 steps. The recommended treatment for children is once in a day for 6 consecutive days. In this study, the respondents received this massage continuously for 4 consecutive weeks.

The respondents who have received massage for 4 cycles of Tui $\mathrm{Na}$ massage appeared to have higher appetite, which in turn has a positive effect on increasing the

Table 1. The respondents' characteristics in the study on the effect of Tui Na massage to the growth status of children under five years of age with KMS T status.

\begin{tabular}{lcccc} 
Characteristics & Control group & Treatment group & Prequency (f) & \\
Child's age & & & 5 & 19.2 \\
$\quad 6$ months - 3 years & 2 & 3 & 21 & 80.8 \\
$\quad 3$ s/d 5 years & 11 & 10 & 11 & 42.3 \\
History of breast milk consumption & & & 15 & 57.6 \\
$\quad$ Exclusive breastfeeding & 5 & 7 & 26 & 100 \\
$\quad$ No exclusive breastfeeding & 8 & 13 & & \\
\hline Total & 13 & & & \\
\hline
\end{tabular}


growth status, in this case is weight gain. The research on the effects of massage on weight gain showed that after the the parents give massage regularly twice in a week for 5 weeks, 11 babies experienced gained weight for more than 1000 grams. ${ }^{12}$ In addition, the research by Dieter on the effects of massage to infants by giving the treatment to premature babies 3 times a day in 5 days with the duration of 15 minutes. It resulted in $53 \%$ greater weight gain compared to the control group. As an addition, previous study in Tawanganom Village, Magetan showed that there was an increase in the weight of the babies aged 3-5 months after receiving the massage. ${ }^{13}$

KMS T growth status of children under five years of age in the control group is not affected by Effleurage massage; and KMS T growth status of children under five years of age in the treatment group is also not affected by Tui $\mathrm{Na}$ massage. Tui $\mathrm{Na}$ is a series of massaging activities performed by several techniques, such as sliding (Effleurage or Tui), massaging (Petrissage or $\mathrm{Nie}$ ), tapping (tapotement or Da), rubbing, pulling, twisting, shaking, and vibrating certain points in the body to affect the body's energy flow by holding and pressing certain body parts. Whereas Effleurage (light massage) is one of the main massage techniques that can be given to all body parts. ${ }^{11}$ Effleurage aims to improve blood circulation, put pressure, and warm the abdominal muscles and improve physical and mental relaxation. Effleurage is an easy, safe massage technique, it does not require a lot of tools and money, and it has no side effects and can be given by ourselves or with the help of others. ${ }^{14}$

The research results did not prove that Tui Na massage affects the growth status of children under five years of age in the treatment and control group. It implies some dominant factors that influence child's physical growth, namely genetic and environmental. The first three years of a child's life is a very important period because of physical growth and development (such as intelligence, motor skills, mental, social, and emotional development) is rapidly progressing in this period. ${ }^{15}$ Besides baby massage, nutritional fulfillment can affect the growth of the baby and the hormone. The baby's growth may also be affected by genetic factors, child's health, immunization, housing, environmental sanitation, chromosomal abnormalities, socio-economics condition, and medicines. Among these factors there are two uncontrollable factors, namely housing and environmental sanitation, in which both factors are likely to contribute to the growth of the baby. Good stimulation for children can be given by parents for maximum potential development. This is in line with the theory which states that the associated factors on the child's growth and development include adequate nutrition and supportive family environment as the basis for child development. ${ }^{16}$

Table 2. Results of descriptive statistics on the growth status of children under five years of age before receiving treatment.

\begin{tabular}{lccc} 
Body weight & Mean & Median & Mode \\
Control group & 9.3 & 10 & 10.0 \\
Treatment group & 10.4 & 10.5 & 7.8 \\
\hline
\end{tabular}

Table 3. Distribution of frequency of growth status of children under five years of age following the treatment in the control and treatment group.

\begin{tabular}{|c|c|c|c|c|c|c|}
\hline Growth status & Increasing & Percentage & Not & Increasing & Percentage & Total \\
\hline Control group & 5 & 38.5 & & 8 & 61.5 & $13(100)$ \\
\hline Treatment group & 10 & 76.9 & & 3 & 23.1 & $13(100)$ \\
\hline
\end{tabular}

Table 4 Analysis results of the effect of Tui Na massage to the growth status of children with KMS T status.

\begin{tabular}{lc} 
Group (test method) & P-value Sig (2-tailed) \\
Before-after (paired t-test) & 0.019 \\
Effleurage-Tui Na (independent t-test) & 0.065 \\
\hline
\end{tabular}

\section{Conclusions}

Based on the results, the study concludes that Tui Na massage can affect the growth status of children under five years of age with KMS T status. In our experiment, Tui Na massage did not affect KMS T growth status of children under five years of age in the control and treatment group, Tui $\mathrm{Na}$ massage in effective for children under five years of age with KMS T growth status.

\section{References}

1. Soetjiningsih. Tumbuh Kembang Anak. Jakarta: EGC; 2008.

2. Hidayat AA, Uliyah M. Kebutuhan Dasar Manusia. Jakarta: Penerbit Buku Kedokteran; 2005.

3. Kementerian Kesehatan Republik Indonesia. Pemantauan status gizi dilakukan di seluruh kabupaten/kota di Indonesia tahun 2015. Available from: http://www.depkes.go.id/article/view/16 032200005/tahun-2015-pemantauanstatus-gizi-dilakukan-di-seluruh-kabupat en-kota-di-indonesia.html. Accessed on: 10 August 2018.

4. UNICEF. UNICEF dan Uni Eropa bersama menangani masalah ketahanan gizi di Asia yang mengkhawatirkan 2011. Available from: https://www.unicef.org/indonesia/id/pus at-pers. Accessed on: 3 March 2018/.

5. Puspita Y. Faktor dan dampak stunting pada kehidupan balita. Dinas Kesehatan Provinsi Bengkulu; 2015.

6. Zhen Huan L, Li-ting C. Effect Tui Na On Neurodevelopment in Premature Infant. J. Acupunct. Tuina. Sci 2013;11(1):7-12.

7. Widodo J. Edukasi dan konsultasi sulit makan dan gangguan kenaikan berat badan. Jakarta: Picky Eaters And Grow Up Clinik; 2012.

8. Limananti AI, Triratnawati A. Ramuan jamu cekok sebagai penyembuhan kurang nafsu makan pada anak. Jurnal Makara kesehatan 2003;7(1):11-20.

9. Hegar B, Suradi R, Hendarto A, et al. Buku Bedah ASI. Jakarta: Sagung Seto; 2008.

10. Utami R. Pedoman pijat bayi. Edisi revisi XIII. Jakarta: Tribulus Agriwidya; 2011.

11. Sukanta P. Okta. Pijat Akupresur Untuk Kesehatan. Jakarta: Penebur Plus; 2010.

12. Sofiani A. Perbedaan Kenaikan Berat Badan Antara Bayi Umur 0-6 Bulan yang di Pijat Bayi dan yang Tidak Dipijat bayi di BPS Yohana Kota Semarang. Semarang: Poltekes 
Abdomen terhadap Penurunan Intensitas Nyeri pada Disminore Primer Mahasiswi PSIK FKUB Malang. Malang: Poltekes Malang; 2011.

15. Adroeni M. Pengaruh Pijat Bayi terhadap Kenaikan Berat Badan Bayi Umur 0-3 Bulan di BPS Saraswati
Sleman Yogyakarta Tahun 2010.

Yogyakarta: Unisa; 2010.

16. Adriana D. Tumbuh Kembang dan Terima Bermain pada Anak. Jakarta: Salemba Medika; 2013. 